\title{
Development of Asphalt Pavement Temperature Models for Oman
}

\author{
H.F. Hassan*1, A.S. Al-Nuaimi1, R. Taha1, and T.M.A. Jafar² \\ ${ }^{1}$ Department of Civil and Architectural Engineering, Sultan Qaboos University, P.O. Box 33, Al Khod 123, Muscat \\ Sultanate of Oman \\ 2 Research and Technical Studies Department, Muscat Municipality, Muscat, Sultanate of Oman
}

Received 6 December 2003; accepted 6 June 2004

\begin{abstract}
تطوير نهاذج لدرجات حرارة الرمف الاسفلتي في عمان
الهستخلص : تعتبر الطرق الأسفلتية جزء رئيسي في أى شبكة نقل، وتعتدد قوة تحمل طبقة رصف الخرسانة الأسفلتية على عدة عوامل من ضهنها درجة الحرارة. هذا بالإضافة لتاثير الحرارة على ظهور أنواع مختلفة من عيوب طبقات الرصف. ولذلك تعتبر الحرارة عاملاً مؤثراً على أداء وعمر طبقات الرصف ـ هذا وقد تطورت شبكة الطرق

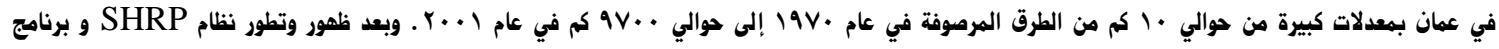
و ظهور نتائج الأبحاث التي اجريت كان لابد من التحقق من تطبيق النهاذج التي طورت من خلال هذا النظام وتدديد دي مناسبة هذه النماذج لظروف عمان المناخية وبصفة أعم لبناخ منطقة الخليج العربي. وتستعرض هذه الورقة نتائج البحث الذي تم إجراؤه لإيجاد نهاذج لتوقع درجات الحراره القصوى و الصغري لطبقات الرصف الأسفلتي في عمان. وقد تم تجهيز موقع وتركيب محطة لقياس درجات حرارة الجو وطبقات الرصف وكذلك الإشعاع الشمسي. وقد تم رصد البيانات لبدة هعء يوم وتدديد درجات الحرارة القصوي والصغري اليومية ، وتم إستخدام طريقة التحليل الإنداري لإيجاد نموذج لدرجات الحراره الصفرى، وطريقة التحليل الإنداري ذو خطوات لإيجاد نهوذج لدرجات الحرارة القصوى بإستخدام درجة حرارة الجو والإشعاع الشمسي وكذلك فتره الإشعاع الشمسي كمتغيرات مستقلة. وقد تم هقارنة النماذج الهطورة في هذه الدراسة مع نهاذج مHRP و البين من الهقارنة ان النهاذج الأخيرة أكثر تحفظاً من النهاذج الهطورة في هذه الدراسة والتي تعتبر أكثر ملائمة لتوقع درجات حرارة الرصف الأسفلتي في عهان وبصفة عامة في منطقة الخليج.

المغردات الهنتاهية : درجة حرارة الرصف، نماذج، شارب، الخرسانة الاسفلتية، عمان.
\end{abstract}

\begin{abstract}
Asphalt pavements form an integral part of any transportation system. The structural capacity of the hot mix asphalt concrete layers depends on many factors including its temperature. Moreover, temperature can be a major contributor to several types of distresses. Therefore, temperature is a significant factor that affects the performance and life span of a pavement. The Sultanate of Oman's road network expanded at a phenomenal pace from approximately $10 \mathrm{~km}$ of paved roads in 1970 to 9,673 km in 2001. with the recent SHRP and LTTP research findings, it was necessary to investigate the applicability of the models developed from these research studies to Oman's environmental conditions and more generally to the Arabian Gulf climate. This paper presents the research undertaken to develop models to predict high and low asphalt pavement temperatures in Oman. A pavement monitoring station was set-up at the Sultan Qaboos University (SQU) campus to monitor air, pavement temperatures and solar radiation. Data were collected for 445 days. Daily minimum and maximum temperatures were recorded. A regression analysis was used to develop the low pavement temperature model. A stepwise regression was used to develop high temperature models using air temperature, solar radiation, and duration of solar radiation as independent variables. The developed models were compared with the SHRP and LTPP models. The SHRP and LTPP models were found to be more conservative than the developed models, which are more suitable for predicting pavement temperatures in Oman, and more generally in the Gulf region.
\end{abstract}

Keywords: Pavement temperature, Models, SHRP, LTPP, Asphalt concrete, Oman

\footnotetext{
*Corresponding authors E-mail: hossam@squ.edu.om
} 


\section{Notation}

\begin{tabular}{|c|c|c|}
\hline $\mathrm{df}$ & $=$ & degree of freedom, \\
\hline $\mathrm{F}$ & $=$ & F statistic, \\
\hline Lat. & $=$ & latitude, \\
\hline MS & $=$ & mean sum of squares, \\
\hline P-value & $=$ & power of the test, \\
\hline $\mathrm{R}^{2}$ - adj. & $=$ & adjusted coefficient of determination \\
\hline $\mathrm{R}^{2}$ & $=$ & coefficient of determination, \\
\hline SEE & $=$ & standard error of estimate, \\
\hline Solar & $=$ & $\begin{array}{l}\text { cumulative solar radiation from dawn to the time of occurrence of maximum air tempera- } \\
\text { ture , W.hr/m², }\end{array}$ \\
\hline SS & $=$ & sum of squares, \\
\hline Std. Error & $=$ & standard error or standard deviation of the coefficient's distribution, \\
\hline $\mathrm{T}_{\text {air }}$ & $=$ & air temperature, ${ }^{\circ} \mathrm{C}$, \\
\hline $\mathrm{t}_{\text {rad }}$ & $=$ & $\begin{array}{l}\text { duration of sunshine from dawn to the time of occurrence of maximum air temperature, } \\
\text { hours, }\end{array}$ \\
\hline t-Stat & $=$ & t statistic, \\
\hline $\mathrm{T}_{\text {surf }}$ & $=$ & pavement surface temperature, ${ }^{\circ} \mathrm{C}$, \\
\hline$\alpha$ & $=$ & level of significance. \\
\hline
\end{tabular}

\section{Introduction}

Asphalt pavements form an integral part of any transportation system. A significant factor that affects the performance and life span of a pavement is the influence of temperature. Temperature can contribute to certain common types of asphalt pavement distresses such as permanent deformation or rutting (typically associated with high temperature environments), bleeding, and thermal cracking (associated with low temperature environments).

The Strategic Highway Research Program (SHRP) established the Long Term Pavement Monitoring Program (LTPP) program in 1987 to support a broad range of pavement performance analyses leading to improved engineering tools to design, construct, and manage pavements Diefenderfer, et al. (2002).

The Seasonal Monitoring Program (SMP) was established as an element of LTPP in 1991 to measure and evaluate the effects of temperature and moisture variations on pavement performance and validate the available models (Mohesni, 1998; Diefenderfer, et al. 2002).

From the initial SHRP testing and SMP data, several pavement temperature models were developed to assist in the proper selection of the asphalt binder performance grade (Mohesni, 1998; Mohesni and Symons, 1998a; Mohesni and Symons, 1998b; Lukanen, 1998; Diefenderfer, et al. 2002). Solaimanian and Kennedy (1993) proposed an analytical model based on the theory of heat and energy transfer. Shao et al. (1997) also developed a procedure based on heat transfer theory to estimate pavement temperatures. Regression models based on other sets of data were developed (Bosscher et al. 1998; Marshall et al. 2001). A simulation model was developed to calculate temperatures during summer conditions based on the heat transfer models developed by Solaimanian and Kennedy (Hermansson, 2000 and 2001; Diefenderfer, et al. 2002).

Al-Abdul Wahhab et al. (1994) conducted a study in two regions in Saudi Arabia to manually measure pavement temperatures in different pavement sections. The study concluded that the extreme pavement temperatures in arid environment ranged between 3 and $72^{\circ} \mathrm{C}$, while in coastal areas, the temperature ranged between 4 and $65^{\circ} \mathrm{C}$. In another study, Al-Abdul Wahhab et al. (1997) recommended five performance graded binder zones for the whole Gulf area. The study also proposed modification of the currently used binders to suite the proposed grades.

The Sultanate of Oman as well as the Gulf area, in general, possesses a different environment from that of the North America. The applicability of the recent SHRP and LTPP developments in the US to Oman's or the Arabian Gulf's environmental conditions needed to be evaluated. This paper presents the research undertaken to develop models to predict high and low asphalt pavement temperatures in Oman. A pavement monitoring station was established at the Sultan Qaboos University (SQU) campus to monitor air, pavement temperatures, and solar radiation. Data was collected for 445 days. Daily minimum and maximum temperatures were recorded. A regression analysis was used to develop the low pavement temperature model. A stepwise regression was used to develop high temperature models using air temperature, solar radiation, and duration of solar radiation as independent variables. The instrumentation used is described and collected data are presented. The developed models were compared with the SHRP and LTPP models. 


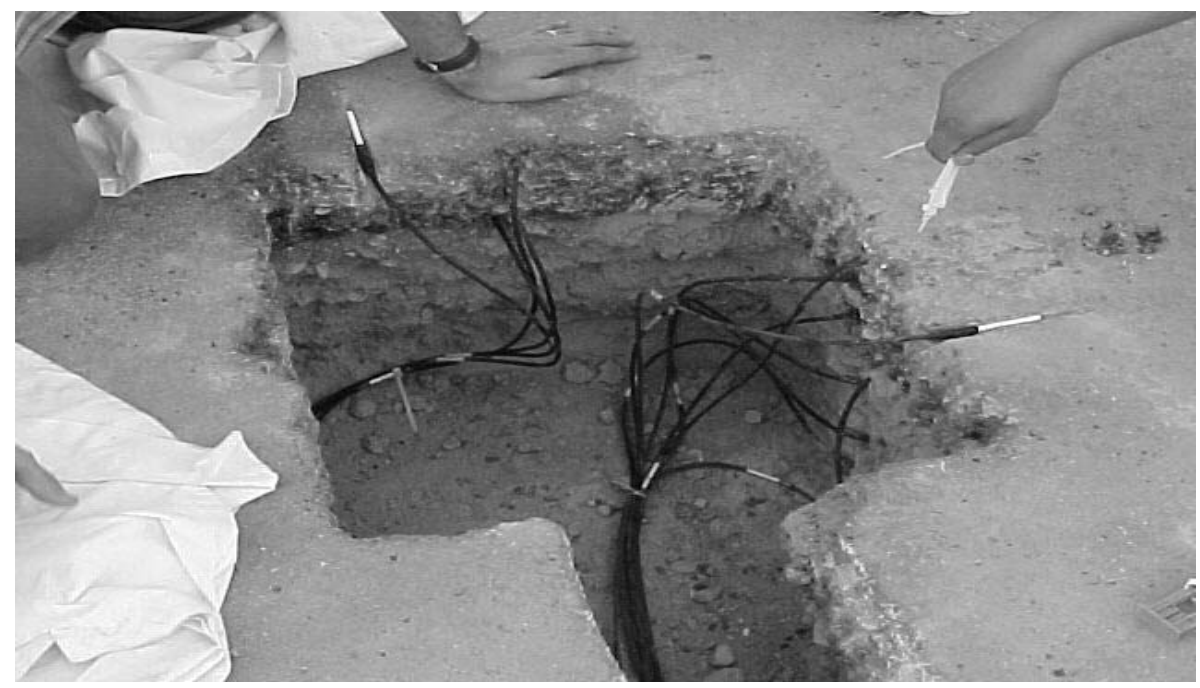

Figure 1. Installation of thermistors

\section{Pavement Temperature Monitoring Station}

A monitoring station was set-up to collect data on air temperature, solar radiation and pavement temperatures at various depths. Sensors were connected to a CR10x Campbell Scientific datalogger housed in a protection enclosure. The enclosure was mounted on an instrumentation tower. The datalogger was operated by a battery. The following section describes the installation and sensor locations.

\subsection{Installation of Station}

A test area 7x8 $\mathrm{m}$ was selected for the station installation inside a newly built parking lot at the Sultan Qaboos University campus. The pavement cross section was modified from the original design in the area of the test section to be composed of $135 \mathrm{~mm}$ of asphalt concrete (AC) wearing course on top of $165 \mathrm{~mm}$ of unbound base course on top of compacted subgrade soil.

After the construction of the pavement was completed, the installation of the sensors was initiated. The procedure started with the excavation of a $500 \mathrm{~mm}$ by $500 \mathrm{~mm}$ by $480 \mathrm{~mm}$ deep pit. A trench $200 \mathrm{~mm}$ wide by $480 \mathrm{~mm}$ deep was also excavated from the pit to where the tower was installed. A fence was erected around the tower area to protect the equipment from damage.

A $50 \mathrm{~mm}$ PVC pipe was laid in the trench to protect the sensor cables extending from the pit to the tower location. All sensors were inserted into the PVC pipe and led to the excavation pit providing adequate slack so as to allow for comfortable installation of the probes at the desired locations.

Two sets of thermistors referred to as center and right, were installed in the center and right sides of the pit. The right set consisted of eight sensors covering the full depth of the excavated pit. The center set had four sensors that covered only the depth of the AC layer to serve as a dupli- cate for the first set. At the targeted sensor locations, a mark was made at the appropriate side of the pit. An electrically powered horizontal and $90^{\circ}$ angle hammer drill was used to drill holes approximately $280 \mathrm{~mm}$ deep into the side of the excavated pit. The $90^{\circ}$ angle was used to accommodate the hammer drill and drilling bit inside the limited pit space.

The process was repeated for each sensor with the exception of those located at the surface (at $0 \mathrm{~mm}$ depth). Holes were cleared of loose debris before sensors were inserted. Sensors were then inserted all the way into the drilled holes and sealed in place using a silicon sealant to prevent concrete or moisture infiltration when backfilling the pit. Figure 1 shows the sensors inserted in the drilled holes at the desired depths.

For surface temperature sensors, a grinder was used to cut through the pavement surface such that the probe could be flush with the pavement surface. The probe was positioned in place and a cold sand asphalt mix was used to seal around it. All actual depths of pavement sensors were measured and recorded. Figure 2 shows a schematic representation of the installation pit showing the layer thicknesses and the actual depth of the sensors.

After adjusting the extra cable lengths, the pit and trench were filled with the subgrade and base material. Compaction of the material was performed manually. Portland cement concrete was used to backfill the pit up to the surface level instead of asphalt concrete due to the ease of backfilling with concrete in addition to the fear of damaging the sensor cables from the hot mix. It was felt that using the concrete instead of asphalt concrete will not affect the readings from the probes, since the sensing tip of the probe (60 mm long) was buried inside the asphalt concrete side of the pit at least $220 \mathrm{~mm}$ away from the interface between the existing pavement and poured concrete.

Finally, the tower was erected and the datalogger solar radiation sensor and air temperature thermistor were mounted on the tower. The sensors were connected to the datalogger. Figure 3 shows an overview of the test area 


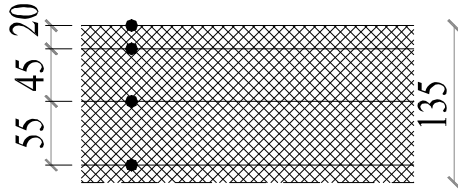

Section - Location of Sensors

(Center)

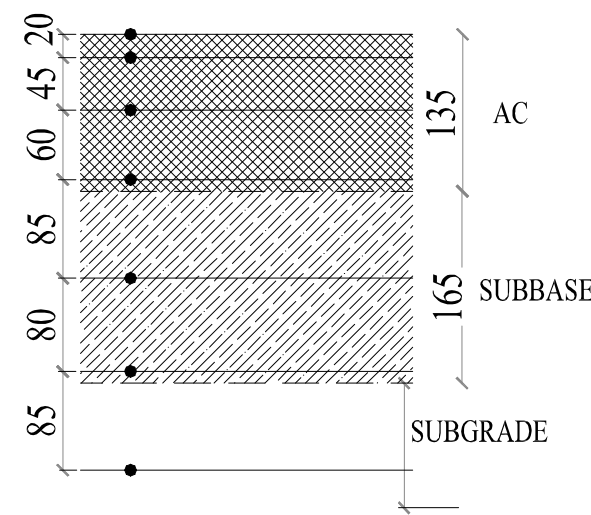

Section - Location of Sensors

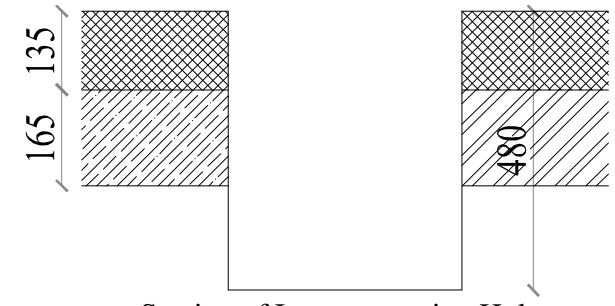

Section of Instrumentation Hole

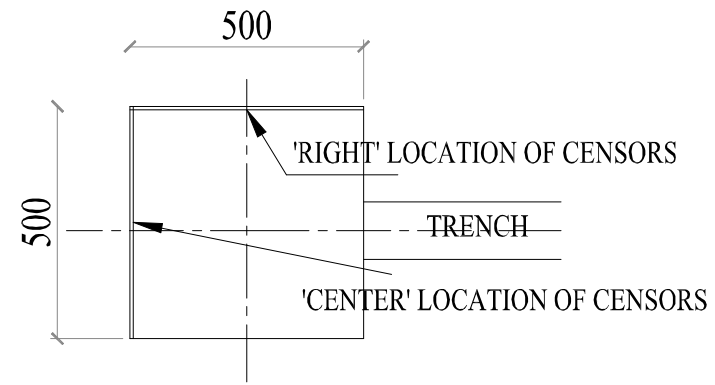

Plan of Instrumentation Hole

(Right)

(Dimensions are in mm)

Figure 2. Pavement layers and thermistor locations

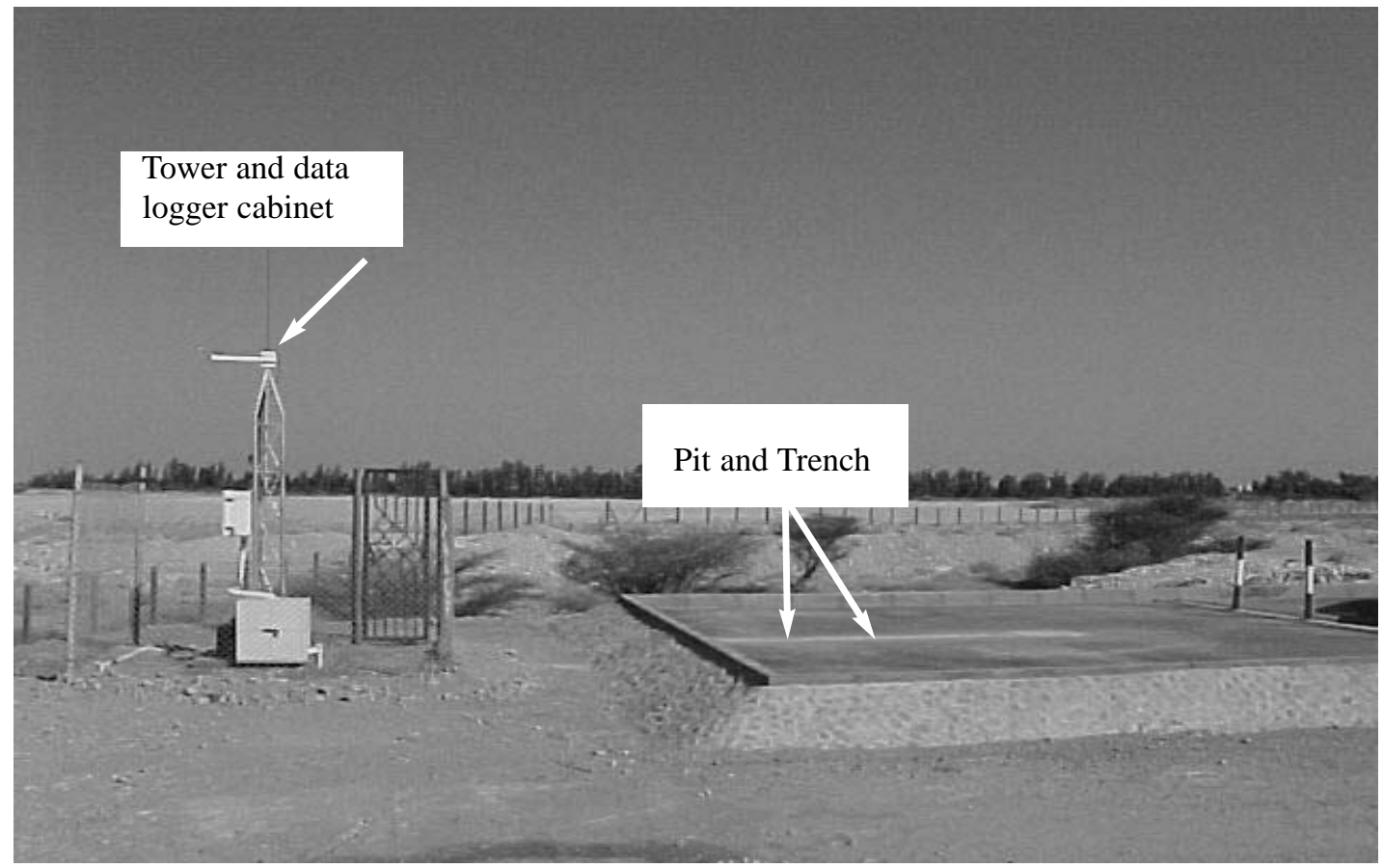

Figure 3. General view of experimental test area 


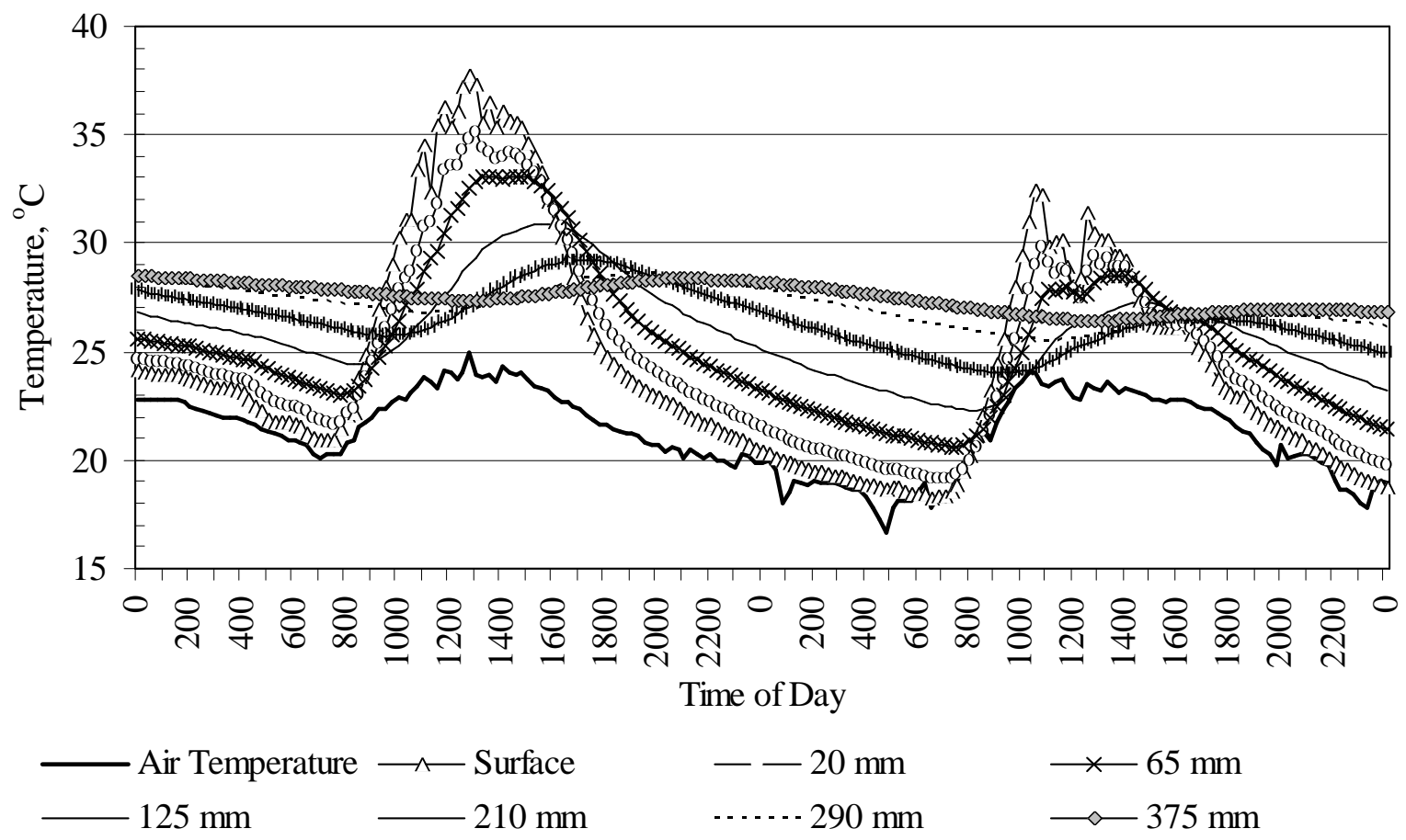

Figure 4. Air and pavement temperature variation on the 24th and 25th December, 2002

after the set-up of the station.

A program was written to operate the CR10x datalogger based on the available sensors configuration. The reading from the solar radiation sensor is taken every minute, and the average value is stored every 15 minutes. All other sensors are read every 15 minutes. Data are stored on the datalogger and downloaded to a computer via a storage module.

\section{Data Analysis}

The temperature data collected were presented to show the different variability patterns between air and pavement temperatures. Pavement temperature models were established using regression analysis on the collected daily maximum and minimum temperatures. The data used to

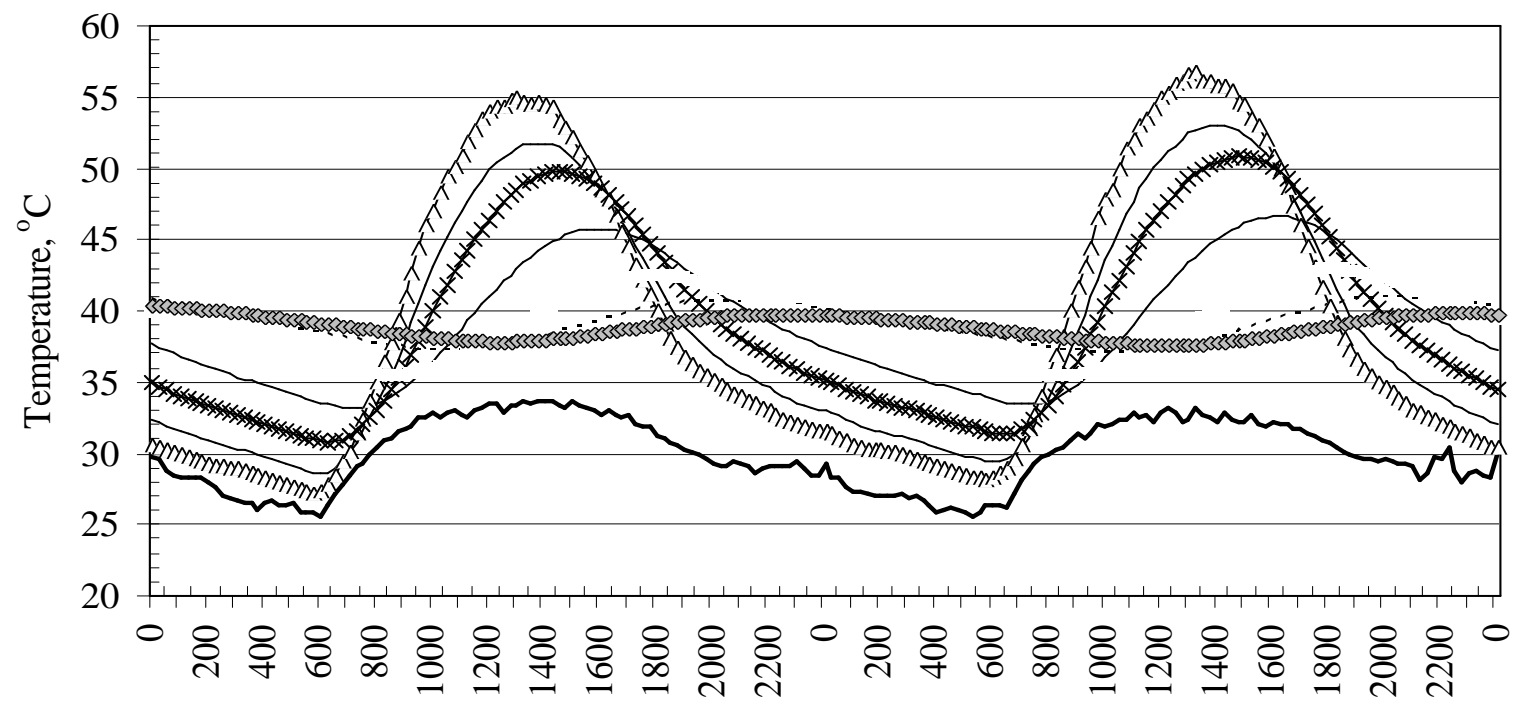

Time of Day
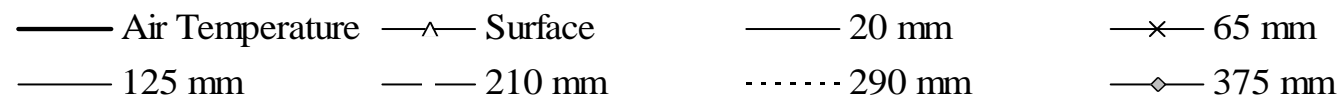

Figure 5. Air and pavement temperature variation on the $2^{\text {nd }}$ and $3^{\text {rd }}$ of May 2003 


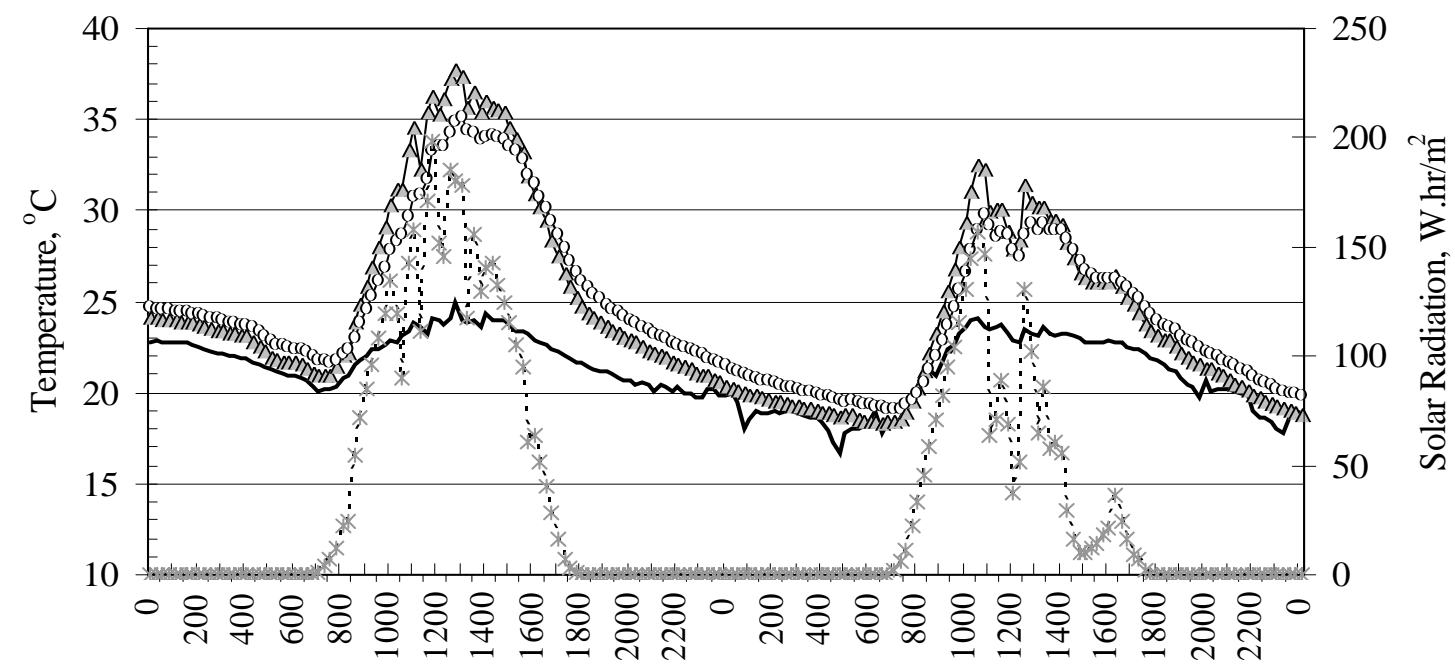

Time of Day

Air Temperature $\longrightarrow$ Surface $\multimap-20 \mathrm{~mm}$ depth -.-*-.- Solar Radiation

Figure 6. Temperature and solar radiation for 24th and 25th of December, 2002

develop the models were collected in the period from $23^{\text {rd }}$ of December 2002 to $6^{\text {th }}$ of April 2004, with a total of 445 days.

\subsection{Temperature Data}

Figures 4 and 5 show the variation of air and pavement temperatures at different depths with the time of day. Fig. 4 shows data obtained for two consecutive days during the cold season; namely the $24^{\text {th }}$ and $25^{\text {th }}$ of December, 2002, while Fig. 5 shows this variation for two consecutive days during the hot season; namely the $2^{\text {nd }}$ and $3^{\text {rd }}$ of May, 2003.

It can be seen that thermistors placed at $290 \mathrm{~mm}$ depth or more (located at the boundary of the subbase and subgrade layers) are less sensitive to changes in the air temperature than sensors located from the surface down to
$210 \mathrm{~mm}$ deep. The surface layer is the layer most sensitive to temperature fluctuations. There is a noticeable time lag in the heating cycle between the maximum air temperature and pavement temperature. In other words, it takes more time to heat the pavement than the air. The time lag increases as pavement depth increases. Time lag is also noticed between the minimum air temperature and pavement temperatures in the cooling cycle. The pavement surface cools quicker than other deeper layers.

Figures 4 and 5 also indicate that the maximum or minimum pavement temperatures occur some time after the occurrence of maximum or minimum air temperature, respectively. The minimum pavement temperature is recorded at the surface but is generally warmer than minimum air temperature. This agrees with the findings reported in the literature.

Figures 6 and 7 show the same data only for the air,

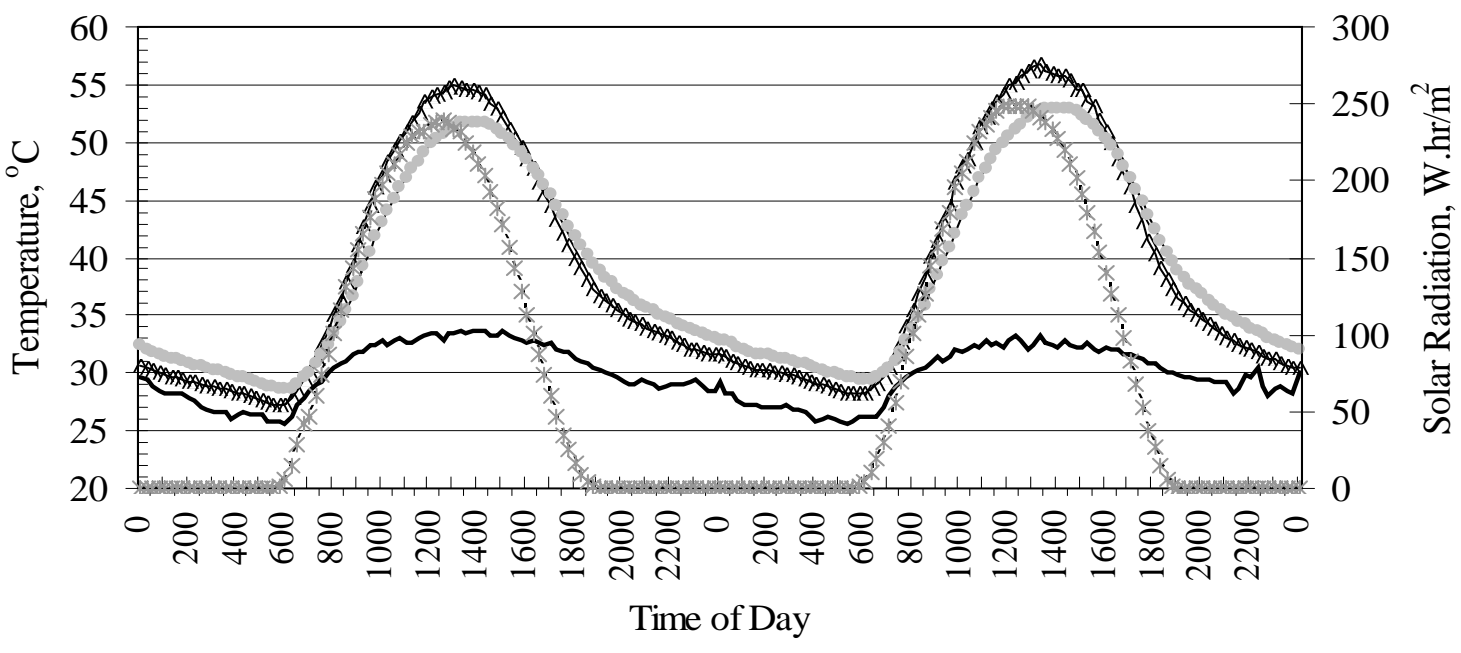

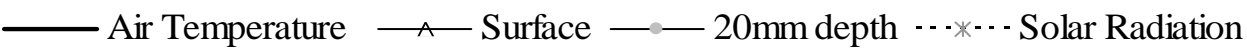

Figure 7. Temperature and solar radiation for $2^{\text {nd }}$ and $3^{\text {rd }}$ of May, 2003 


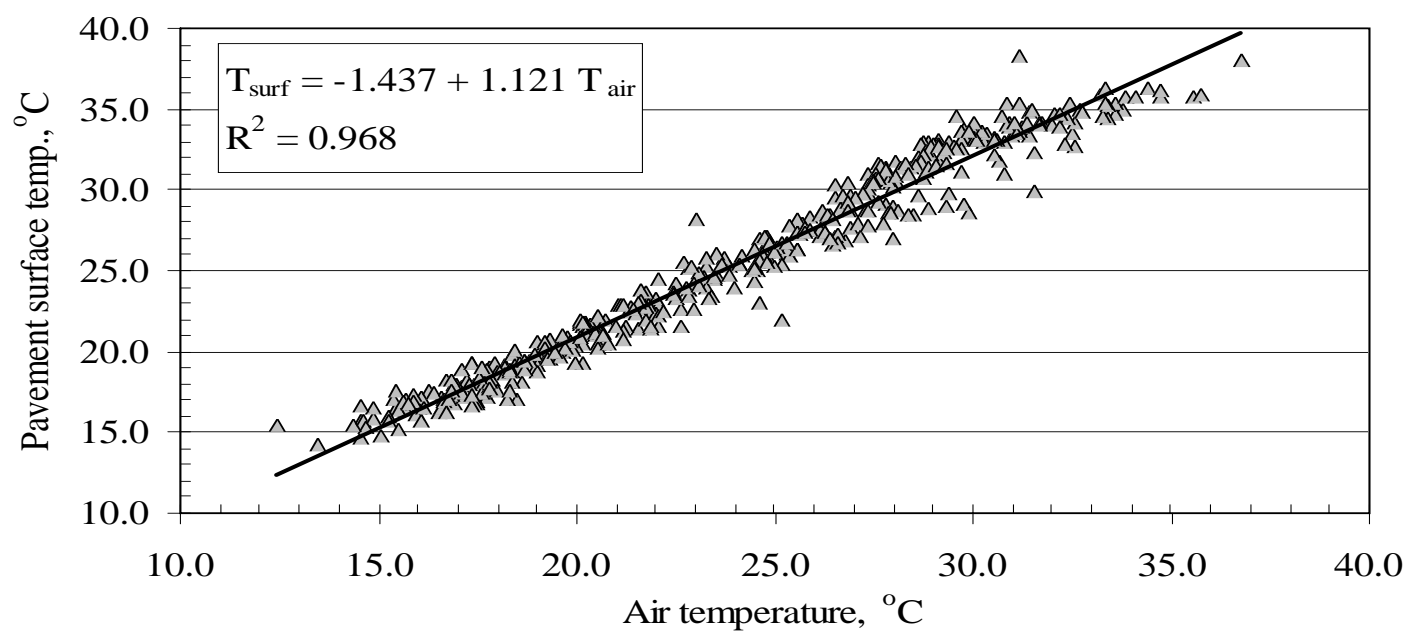

Figure 8. Developed low pavement temperature prediction model

surface and $20 \mathrm{~mm}$ sensors, in addition to the solar radiation. Fig. 4 illustrates some fluctuation in temperatures detected by the air temperature sensor and the sensors placed at the surface and $20 \mathrm{~mm}$ depth. This is more clearly illustrated in Fig. 6 where the readings obtained for solar radiation as well as the readings from the surface and $20 \mathrm{~mm}$ sensors are plotted. This effect is not seen in hotter conditions (Fig. 7). This can be explained by the cloudy weather conditions encountered in winter that shade the sun's rays, as shown by the fluctuation in solar radiation readings presented in Fig. 6.

It can also be seen that the temperature of the pavement at greater depths is warmer than those placed nearer to the surface at night time. This pattern is maintained until the minimum air temperature is reached, and the pattern is reversed with the surface layers becoming warmer and gain energy from the sun rays during the day while the deeper layers become cooler.

\subsection{Development of Low Temperature Model}

The low pavement temperature model was established using air temperature as an independent variable and pavement surface temperature as the dependant variable. The lowest air temperature in any single day was identified for the entire period during which data were collected and the corresponding daily minimum pavement temperature at the surface was obtained. A regression analysis was per- formed using Minitab statistical software to develop the model (Neter et al., 1990; MINITAB, 2000). The model was developed using 445 data points.

$\mathrm{T}_{\text {surf }}=-1.437+1.121 \mathrm{~T}_{\text {air }}$

where, $\mathrm{T}_{\text {surf }}=$ minimum pavement temperature, ${ }^{\circ} \mathrm{C}$ and $\mathrm{T}_{\text {air }}$ $=$ minimum air temperature, ${ }^{\circ} \mathrm{C}$.

This relationship with the collected data is illustrated in Figure 8. The model achieved a Goodness-of-Fit $\left(\mathrm{R}^{2}\right)$ of 0.968 and a standard error of estimate (SEE) of $1.11^{\circ} \mathrm{C}$. Table 1 shows the ANOVA results for the model. It is to be noted that the lowest pavement temperatures recorded in Oman are well above the low pavement temperatures typically encountered in the US. This is due to the Gulf area climate which does not have subfreezing temperatures.

\subsection{Development of High Pavement Temperature Models}

The highest air temperaure and the highest pavement temperature at a depth of $20 \mathrm{~mm}$ below the surface for each day were identified. A linear regression was performed using the highest air temperature as the independent variable and the highest $20 \mathrm{~mm}$ pavement temperature as the dependent variable. Using 445 days of collected data, the following equation was obtained:

Table 1. ANOVA table for low temperature model ${ }^{*}$

\begin{tabular}{|c|c|c|c|c|}
\hline & df & SS & MS & $\mathbf{F}$ \\
\hline Regression & 1 & 16155 & 16155 & 13150.93 \\
\hline Residual & 443 & 544 & 1 & \\
\hline \multirow[t]{2}{*}{ Total } & 444 & 16699 & & \\
\hline & Coefficients & Std. Error & t-Stat & P-Value \\
\hline Intercept & -1.4373 & 0.239 & -6.02 & 0.000 \\
\hline Variable & 1.1208 & 0.010 & 114.68 & 0.000 \\
\hline
\end{tabular}

$* \mathrm{df}=$ degree of freedom; $\mathrm{SS}=$ sum of squares; $\mathrm{MS}=$ mean sum of squares, $\mathrm{F}=\mathrm{F}$ statistic, Std.Error $=$ standard error or standard deviation of the coefficient's distribution 


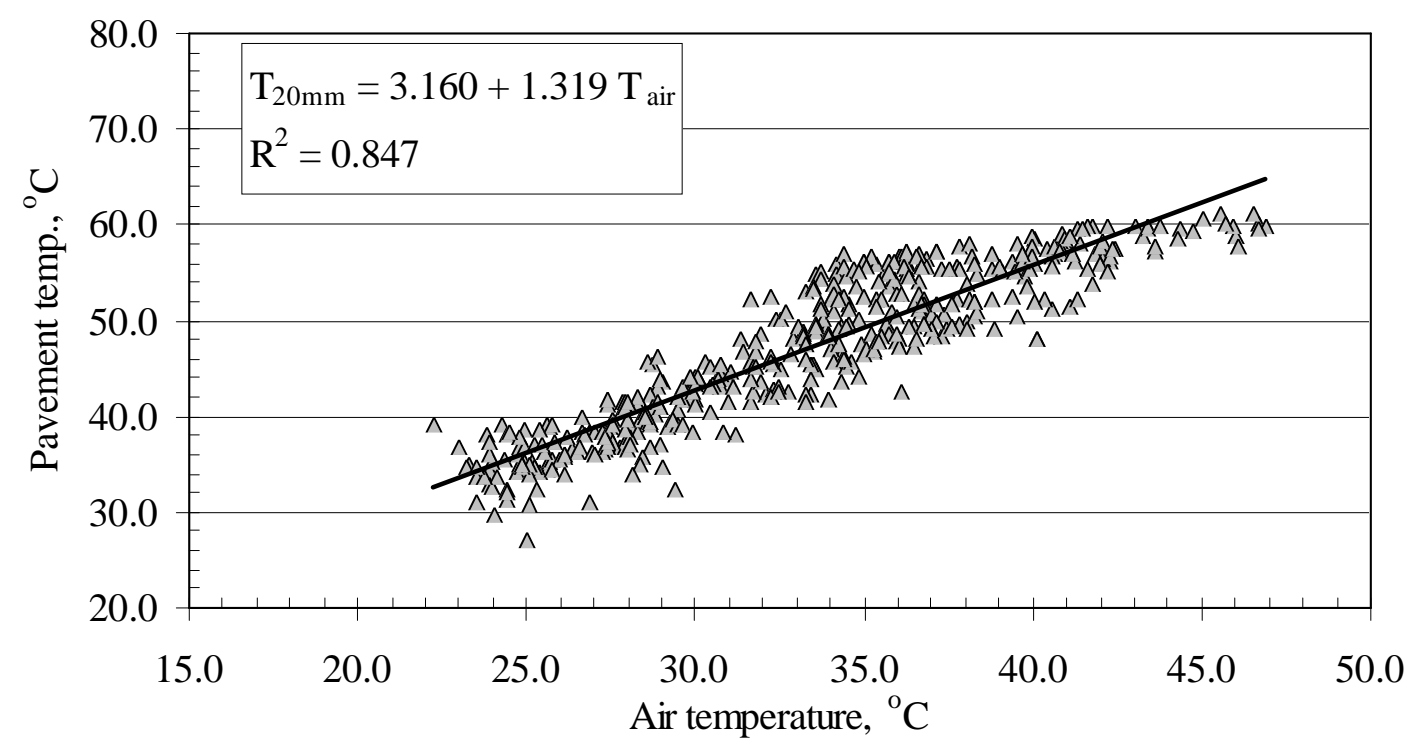

Figure 9. Developed high pavement temperature prediction model

$\mathrm{T}_{20 \mathrm{~mm}}=3.160+1.319 \mathrm{~T}_{\text {air }}$

where, $\mathrm{T}_{20 \mathrm{~mm}}=$ pavement temperature at $20 \mathrm{~mm}$ depth, ${ }^{\circ} \mathrm{C}$ and $\mathrm{T}_{\text {air }}=$ maximum air temperature, ${ }^{\circ} \mathrm{C}$.

Figure 9 shows the data collected as well as the regression equation obtained. The equation achieved an $\mathrm{R}^{2}$ of 0.847 and an SEE of $3.18^{\circ} \mathrm{C}$. Table 2 shows the ANOVA results for the model.

Since high pavement temperature is affected by factors other than air temperature, other parameters were considered with the aim of improving $\mathrm{R}^{2}$ of the model. Three variables were considered as independent variables: air temperature $\left(\mathrm{T}_{\text {air }}\right)$, cumulative solar radiation from dawn to the time at which the maximum air temperature occurred (Solar), and the duration over which solar radiation is accumulated $\left(\mathrm{t}_{\mathrm{rad}}\right)$. The pavement temperature at 20 $\mathrm{mm}$ depth was taken as the dependant variable. In order to obtain the best model, a stepwise regression was performed. The accumulated solar radiation was considered as this is the energy that the pavement absorbs and contributes to the highest pavement temperature. The dura- tion to the maximum pavement temperature would have been more appropriate to consider, however, the identification of the maximum pavement temperature would not be possible at other weather stations where no pavement sensors would be available.

The addition and removal of variables were allowed in the stepwise regression procedure. The Partial F-test was used to verify for the entry and removal of variables from the model. The stepwise regression resulted in one additional model. Thus, a second model was developed using pavement temperature as the dependent variable, and air temperature and cumulative solar radiation as the independent variables. The developed equation was as follows:

$\mathrm{T}_{20 \mathrm{~mm}}=2.713+1.281 \mathrm{~T}_{\mathrm{air}}+0.00053$ Solar

where, Solar $=$ cumulative solar radiation from dawn to the time of occurrence of maximum air temperature in $\mathrm{W} . \mathrm{h} / \mathrm{m}^{2}$. $\mathrm{R}^{2}$ increased and SEE decreased slightly compared to the first model (Eq. 2) to 0.854 and $3.12^{\circ} \mathrm{C}$, respectively.

Table 2. ANOVA table for high temperature model with air temperature variable*

\begin{tabular}{lcccc}
\hline & df & SS & MS & F \\
\hline Regression & 1 & 24512 & 24512 & 2416.44 \\
Residual & 435 & 4413 & 10 & \\
Total & 436 & 28925 & & \\
\hline \multicolumn{1}{l}{ Intercept } & Coefficients & Std. Error & t-Stat & P-Value \\
Variable & 3.160 & 0.907 & 3.48 & 0.001 \\
\hline
\end{tabular}

* Same notations as in Table 1 
Table 3. Stepwise regression analysis for high pavement temperature model

\begin{tabular}{lcc}
\hline \multicolumn{1}{c}{ Step } & $\mathbf{1}$ & $\mathbf{2}$ \\
\hline Constant & 3.160 & 2.713 \\
\hline $\mathrm{T}_{\text {air }}$ & 1.319 & 1.281 \\
t-stat. & 49.16 & 46.14 \\
P-Value & 0.000 & 0.000 \\
\hline Solar & & 0.00053 \\
t-stat. & & 4.32 \\
P-Value & & 0.000 \\
\hline SEE & 8.18 & 3.12 \\
$\mathrm{R}^{2}$ & 84.74 & 85.37 \\
$\mathrm{R}^{2}$ adj. & 84.71 & 85.31 \\
\hline$\sigma$ for entry $=0.05, \alpha$ to remove $=0.05$ &
\end{tabular}

Table 3 shows the results of the stepwise regression. The analysis used the same level of significance (0.05) to add or remove variables. Using the partial F-test, if the $\mathrm{P}$ value is less than 0.05 , then there is enough evidence that the variable is not zero at 0.05 level of significance and the variable should be kept. Otherwise, the variable should be removed. The table shows that the $\mathrm{P}$ value is less than 0.05 in both models.

The third parameter $\left(t_{r a d}\right)$ was removed from the model as the $\mathrm{P}$ value was more than 0.05 . A correlation between the cumulative solar radiation and the duration $\left(\mathrm{t}_{\mathrm{rad}}\right)$ variables was found to be 0.839 as expressed by the Pearson product moment correlation coefficient. This shows a strong correlation between the two variables, and supports the removal of the $\left(t_{\text {rad }}\right)$ variable.

The use of the developed relationships depends on the availability of data. Equation 2 can be used if only air temperature measurements are available. The more accurate model Eq. 3 can be used if solar radiation measurements are available. It should be noted that solar radiation may be estimated using the relationship described in details by Diefenderfer et al. (2002) which estimates solar radiation using the geographical latitude of any given location and day of the year.

\section{Comparison of Developed Models with SHRP and LTPP Models}

\subsection{Low Temperature Model}

Figure 10 shows a comparison between the developed low temperature model and SHRP and LTPP low temperature prediction models for pavement surface temperature. The collected field data are also shown in Fig. 10. The SHRP and LTTP low temperature models are given by the following relationships, respectively Mohseni, (1998):

$$
\begin{aligned}
& \mathrm{T}_{\text {surf }}=0.859 \mathrm{~T}_{\text {air }}+1.7 \\
& \mathrm{~T}_{\text {surf }}=1.56+0.72 \mathrm{~T}_{\text {air }}-0.004 \mathrm{Lat}^{2}+6.26 \log _{10}(25)
\end{aligned}
$$

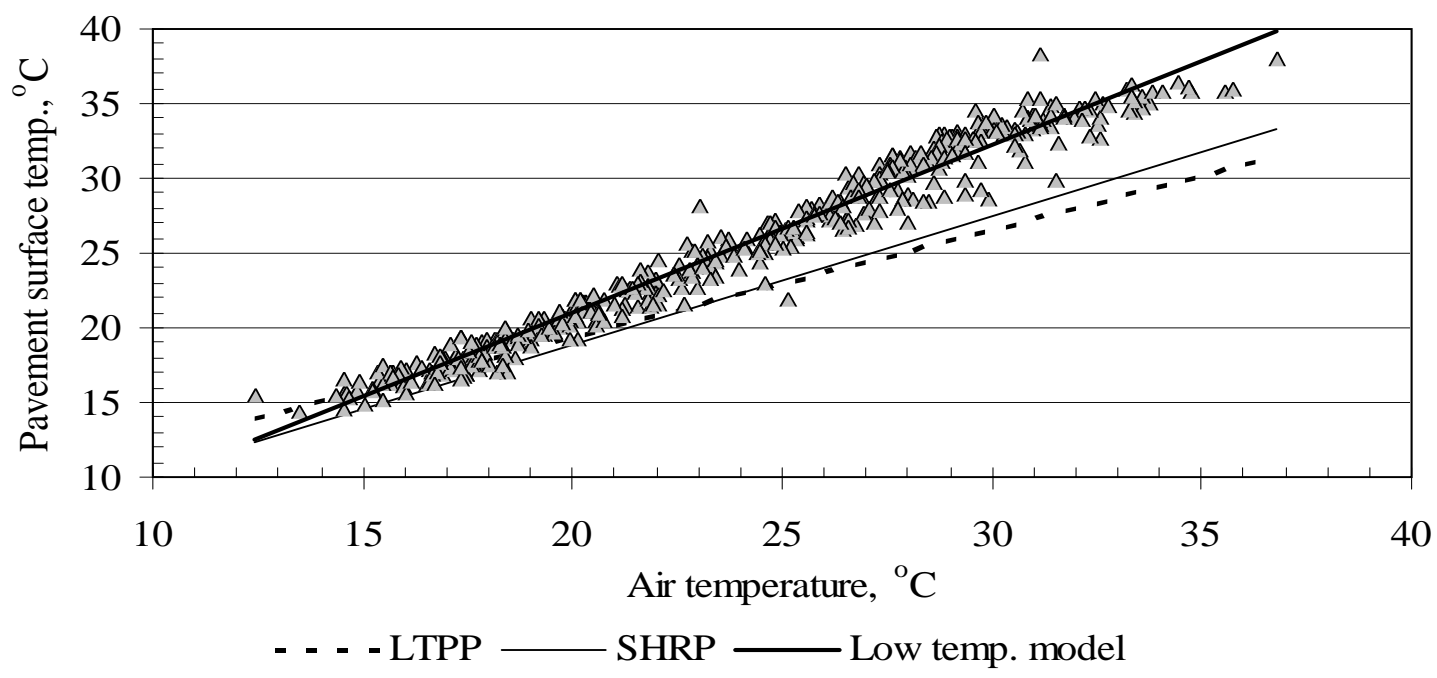

Figure 10. Comparison between low pavement temperature prediction model and SHRP and LTTP models 
where, $\mathrm{T}_{\text {surf }}=$ pavement surface temperature, $\mathrm{T}_{\text {air }}=$ air temperature, and Lat=latitude. The latitude was substituted with the Seeb International Airport (Muscat) latitude, which is $23^{\circ} 35^{\prime} 00^{\prime \prime}$.

Figure 10 clearly shows that the predicted SHRP and LTPP low pavement temperature is lower than both the measured values and the low pavement temperature predicted by the developed model. Both models tend to be closer to both the collected data and the developed model at temperatures less than $15^{\circ} \mathrm{C}$. This indicates that the developed model is more suitable for Oman's climate and that SHRP and LTPP models would be more conservative in the Performance Grade (PG) binder selection.

\subsection{High Pavement Temperature Models}

Figure 11 shows a graphical comparison between the developed high pavement temperature prediction model, SHRP and LTPP models. The collected data are also presented. SHRP and LTPP models are given by the following relationships, respectively Mohesni, (1998):

$$
\begin{aligned}
\mathrm{T}_{20 \mathrm{~mm}}= & \left(\mathrm{T}_{\text {air }}-0.00618 \text { Lat }^{2}+0.2289 \text { Lat }+42.4\right) \\
& 0.9545-17.78 \\
\mathrm{~T}_{20 \mathrm{~mm}}= & 54.32+0.78 \mathrm{~T}_{\text {air }}-0.0025 \text { Lat }^{2} \\
& -15.14 \log _{10}(45)
\end{aligned}
$$

where, $\mathrm{T}_{20 \mathrm{~mm}}=$ pavement temperature at $20 \mathrm{~mm}$ depth, $\mathrm{T}_{\text {air }}=$ air temperature, and Lat=latitude. The latitude was replaced with Muscat latitude.

Figure 11 illustrates that the predicted SHRP and LTPP high pavement temperature at $20 \mathrm{~mm}$ are higher than both the measured values and the high pavement temperature predicted by the developed model. Therefore, the developed model is more representative of Oman's climatic conditions. SHRP and LTPP models would be expected to result in a more conservative selection of the PG binder.

\section{Conclusions}

The following conclusions can be drawn from the analysis of the data collected in this research:

1. A pavement temperature monitoring station was set-up on Sultan Qaboos University campus. The collected data indicated the expected trends for cycles of heating and cooling of the pavement layers.

2. A low pavement temperature model was developed for Oman based on air temperature as an independent variable. The model achieved an $\mathrm{R}^{2}$ of 0.968 .

3. The low temperature model, when compared with SHRP and LTPP, showed that the two later models provide lower estimate of pavement temperature compared with the developed model. SHRP and LTPP models are more conservative in the selection of Performance Grade (PG) binders, and the developed model would be more suitable for Oman's climate.

4. Two high pavement temperature models were developed, taking into account air temperature and cumulative solar radiation from dawn to the time of maximum air temperature as independent variables to predict the high pavement temperature at $20 \mathrm{~mm}$ depth. A stepwise regression analysis was used to develop the models. The models achieved $\mathrm{R}^{2}$ values of 0.847 and 0.854 with the addition of the air and solar radiation variables, consecutively. The partial F-test indicated that the duration of solar radiation up to the maximum air temperature variable for the three variables model should be removed at 0.05 level of significance.

5. The comparison of high pavement temperature model using only air temperature as an independent variable with SHRP and LTPP models indicated that the latter models would estimate higher pavement temperatures

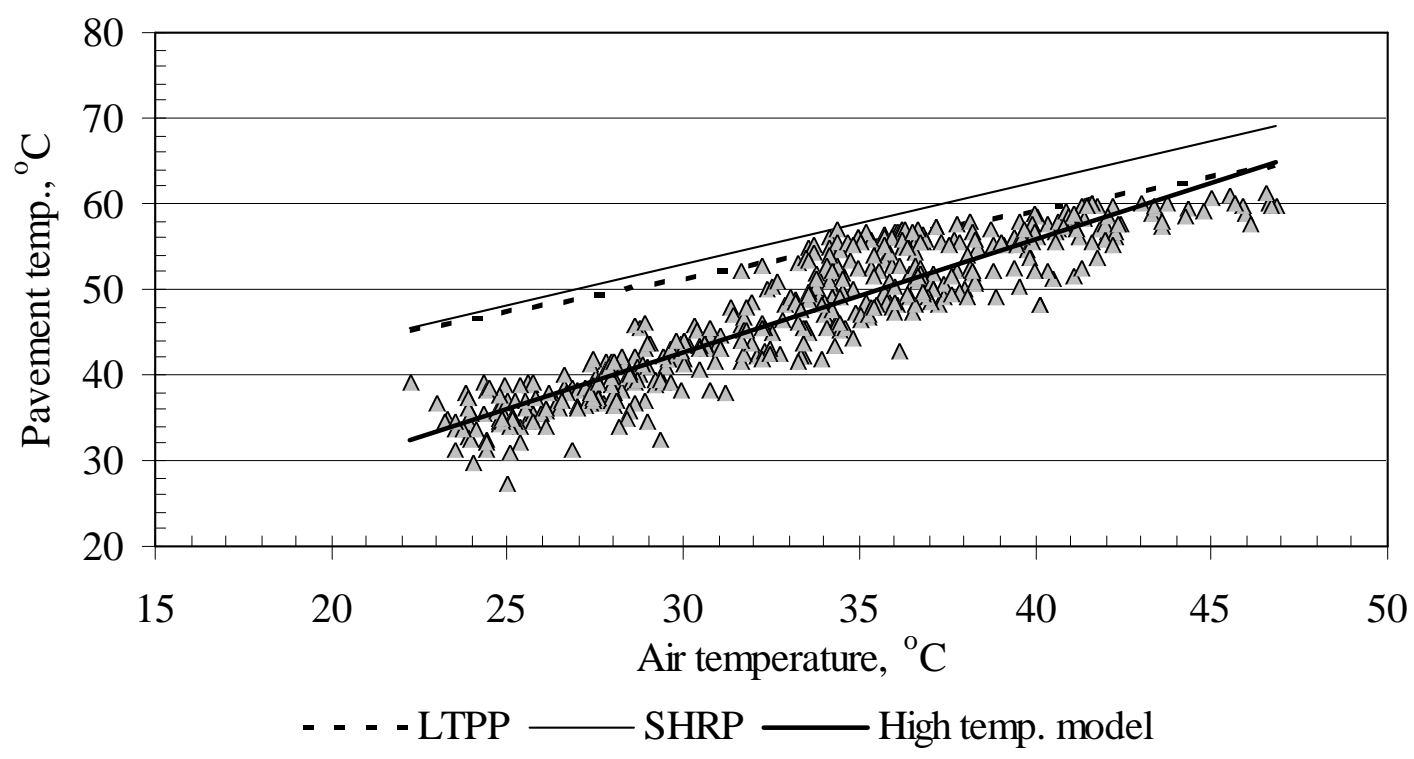

Figure 11. Comparison between high pavement temperature prediction model and SHRP and LTPP models 
for Oman. Therefore, these models would be conservative in the selection of Performance Grade (PG) binders for Oman compared with the developed model.

6 . The use of the high pavement temperature model would depend on the availability of data. If solar radiation measurements are available or can be estimated, then the two variable model can be used.

\section{Acknowledgments}

The authors gratefully acknowledge the financial support by Sultan Qaboos University through an internal research grant. The authors acknowledge the help provided by the Project and Maintenance Department in the University for the station installation.

\section{References}

Al-Abdul Wahhab, H.I. and Balghunaim, F.A., 1994, "Asphalt Pavement Temperature Related to Arid Saudi Environment," J. of Materials in Civil Engineering, American Society of Civil Engineers, 6 (1), pp. 1-14.

Al-Abdul Wahhab, H.I., Asi, I.M., Al-Dubabe, A. and Ali, M.F., 1997, "Development of Performance-Based Bitumen Specifications for the Gulf Countries," Construction and Building Materials, 11(1), pp. 15-22.

Bosscher, P. J., Bahia, H. U., Thomas, S. and Russell, J. S., 1998, "The Relation Between Pavement Temperature and Weather Data: A Wisconsin Field Study to Verify the Superpave Algorithm," Transportation Research Record 1609, TRB, National Research Council, Washington, DC, pp. 1-11.

Diefenderfer, B.K., Al-Qadi, I.L., Reubush, S.D. and Freeman, T.E., 2002, "Development and Validation of A Model to Predict Pavement Temperature Profile," Presented at Transportation Research Board 82nd Annual Meeting, Washington DC.

Hermansson, A., 2000, "Mathematical Model for Calculation of Pavement Temperatures: Comparisons of Calculated and Measured Temperatures," Transportation Research Record 1699, TRB, National Research Council, Washington, DC, pp. 134-141.

Hermansson, A., 2001, "Mathematical Model for
Calculation of Pavement Temperatures: Comparisons of Calculated and Measured Temperatures," Transportation Research Record 1764, TRB, National Research Council, Washington, DC, pp. 180-188.

Lukanen, E. O., Han, C. and Skok, E. L. Jr., 1998, "Probabilistic Method of Asphalt Binder Selection Based on Pavement Temperature," Transportation Research Record 1609, TRB, National Research Council, Washington, DC, pp. 12-20.

Marshall, C., Meier, R.W. and Welsh, M., 2001, "Seasonal Temperature Effects on Flexible Pavements in Tennessee," Presented at Transportation Research Board 80th Annual Meeting, Washington, DC.

MINITAB Statistical Software Release 13, 2000, User's Guide, Minitab Inc.

Mohseni, A., 1998, "LTPP Seasonal Asphalt Concrete (AC) Pavement Temperature Models," Report FHWA-RD-97-103, Federal Highway Administration, U.S. Department of Transportation, p. 71.

Mohseni, A. and Symons, M., 1998a, "Effect of Improved LTPP AC Pavement Temperature Models on Superpave Performance Grades," Presented at Transportation Research Board 77th Annual Meeting, Washington, D.C.

Mohseni, A. and Symons, M., 1998b, "Improved AC Pavement Temperature Models from LTPP Seasonal Data," Presented at Transportation Research Board 77th Annual Meeting, Washington, D.C.

Neter, J., Wasserman, W. and Kunter, M.H., 1990, "Applied Linear Statistical Models," Third Edition, Richard D. Irwin, Inc., Boston, p. 1181.

Shao, L., Park, S.W. and Kim, Y.R., 1997, "A Simplified Procedure for Prediction of Asphalt Pavement Subsurface Temperatures Based on Heat Transfer Theories," Transportation Research Record 1568, TRB, National Research Council, Washington, DC, pp. 114123.

Solaimanian, M. and Kennedy, T.W., 1993, "Predicting Maximum Pavement Surface Temperature Using Maximum Air Temperature and Hourly Solar Radiation", Transportation Research Record 1417, TRB, National Research Council, Washington, DC, pp. 1-11. 